\title{
STUDY OF DENSITY OF RASPBERRY FRUITS IN VIEW OF MECHANIZED HARVESTING
}

\author{
Natalia Bogomolova ${ }^{1, *}$, Svetlana Rezvyakova ${ }^{2}$, and Maxim Lupin ${ }^{1}$ \\ ${ }^{1}$ All-Russian Research Institute of Fruit Crops Breeding,. 302530 Russia, Oryol Oblast, Oryol district, Jilina village, 1 \\ ${ }^{2}$ Oryol State Agrarian University named after N.V. Parakhin, 302019 Russia, Oryol, Generala Rodina Str., 69
}

\begin{abstract}
The paper discusses the possibility of combining large-fruits and density of raspberries as one of the main and decisive limiting indicators of the suitability of varieties for mechanized cultivation and further harvesting, as well as for long-term transportation to the consumer. The objects of research were 20 raspberry varieties and 15 elite forms from controlled crossings and populations from free pollination. The annual assessment of the density of raspberries was carried out at the collection and selection plots during the period of active fruiting (June-July-August) 2019-2020. From each variety sample, 10 berries were taken at full maturity. The berry crushing force was determined using the fruit test device. The climatic conditions of the study periods were rich in contrast, which indicates the instability of climatic factors of the summer growing season. This made it possible to fairly objectively evaluate the collection and breeding material in terms of the size and density of raspberries. Assessing the crushing force of collection and elite forms of raspberries made it possible to identify varieties having the increased fruit density. Rannyaya Zarya, Lyachka and Lazarevskaya have a relatively large (3.5-4.5 g) and dense berry with a crushing force of 7.6-8.4 N. The interesting elite forms are 9-58; 9-27; 9-20 with a berry mass of 3.8-4.0 $\mathrm{g}$ and a crushing force of 7.3-9.7-N. The crushing force of fruits of these elite forms during the study period was not lower than $5.0 \mathrm{~N}$, but sometimes it was significantly influenced by soil and air moisture, which negatively affected the commercial qualities of berries.
\end{abstract}

\section{Introduction}

Raspberry is one of the economically viable and profitable berry crops. The total volume of world production of raspberries in 2013 amounted to 578.233 tons. Russia supplied $25 \%$ of this volume, which amounted to 143.0 ths. tons. According to the Food and Agriculture Organization FAOSTAT data for 2017, other large producers of raspberries are Poland (121.0 ths. tons), the USA (91.3 ths. tons), Serbia (68.5 ths. tons), and Mexico (30.4 ths. tons). The area of industrial plantations of this berry crop in the world is 118,219 hectares, of which 20185 hectares is in the Russian Federation, 21861 hectares in Serbia, 29317 hectares in Poland, 8722 hectares in the USA, 6390 hectares in Mexico [1].

The fruits of this culture have unique dietary and medicinal properties, and serve as valuable raw materials for the food and confectionery industries. Given this, it is necessary to expand the main production areas using highly efficient mechanized technologies in specialized farms. The main element of such technologies is machine harvesting. It was established that manual collection of berries accounts for up to $70-80 \%$ of the costs associated with the cultivation of crops, while mechanization of harvesting can reduce it by 10-12 times and reduce direct operating costs by $50-70 \%$ [2].
The raspberry culture came from Europe. The annual production of raspberries in the world reaches 900 thousand metric tons per year. Fruits harvested in early to mid-summer are usually used for commercial sale in fruit markets and individual quick freezing (IQF), in the production of juices and dried fruits. These berries are an excellent source of fiber and antioxidants. The content of dietary fiber in these fruits is $6.5 \mathrm{~g}$, and in strawberries it is $2 \mathrm{~g}$ [3]. Raspberries have a high variety of vitamin content. It contains vitamins A, E, and groups B1, B2, $\mathrm{B} 3$, B5, B6, and vitamin $\mathrm{K}$. These berries are rich in zinc, copper, magnesium, manganese, and iron, they contain potassium and a little sodium. Raspberries contain flavonoids that act as "housekeeping" agents in the brain to remove any oxidative stress such as free radicals in brain cells. Their main role is to "clear" toxic compounds from brain tissue that usually leads to dysfunctions such as Alzheimer's and Parkinson's [3]. Raspberry flavonoids help to lower blood levels of lowdensity lipoprotein (LDL) and reduce inflammation. The high concentration of LDL in the body leads to the formation of plaque in the arteries. The most dangerous sites for plaque formation are in the blood vessels of the heart, also known as coronary arteries. Blockage of these arteries leads to a decrease in blood flow to the heart muscle, myocardium. Reduced blood flow or blockage

\footnotetext{
* Corresponding author: bogomolova@vniispk.ru
} 
of these blood vessels will lead to heart attack and, if left untreated, death [3].

Currently, scientists in more than 24 countries of the world are engaged in raspberry selection. At the National Institute of Agricultural Botany (England), the former East Malling Experimental Station, a serious selection work with raspberries has been carried out since 1950 . At that time, the most popular large-fruited varieties Malling Promise, Malling Exploit and a very popular variety, Malling Jewel were developed [4]. Later, the variety Octavia [5] was obtained, which has a later ripening period, thereby it completely reduces the gap between early and late harvest in Great Britain, in particular in Scotland. Breeding remontant varieties on annual shoots, created in the early 1980s is currently relevant in the world raspberry selection. Autumn Bliss was very popular during the initiation of the industrial plantations of remontant raspberries in many countries, which contributed to the widespread of this crop throughout the world and active promotion in many European countries.

The Autumn Treasure raspberry variety was obtained much later and was a good source of plant resistance to late blight, and also has high-quality fruits with a rich biochemical composition [6].

The Scottish Crop Research Institute (James Hutton Institute) (Invergowery, UK) has created raspberry varieties of the Glen series. The first introduced variety in this series is Glen Clova (1969). Glen Moy and Glen Prosen were created in 1981, which were distinguished by their large fruit size, the absence of thorns, and good dessert qualities.

The absence of thorns and the straight growth of shoots is a system of features of raspberry varieties suitable for mechanized harvesting. Until now, Glen Ample has been the most popular variety, which was created in 1996 and is the standard in the European raspberry wholesale market. The variety is suitable both for processing and for the market of fresh berries [4-6]. Later, industrial varieties were created, of which Glen Fyne is well suited for mechanized berry picking, Glen Ericht exhibits high and stable field resistance to late blight, Glen Dee and Glen Carron are distinguished by large, dense fruits and long shelf life [4-6].

Among the European countries, Poland is one of the main producers of raspberries in the European Union. At the Institute of Horticulture, the main remontant varieties of early and medium ripening have been created, Polana and Polka are widely used in industrial cultivation. They are also actively used as parental forms in breeding. During the implementation of the NIWA breeding program, high-yielding remontant and summer varieties were obtained: Laszka, Radziejowa, Sokolica and Przehyba [7, 8], as well as new modern raspberry varieties for industrial cultivation: Polonez, Poemat and Delniwa. Polka has the greatest commercial success in Europe, which has proven itself well in industrial mechanized cultivation technology [7, 8].

In the United States, raspberries are industrially cultivated throughout most of the country. Mostly industrialized, highly profitable plantations are concentrated around the Pacific Northwest Coast in
California, Washington DC, and Oregon. The Raspberry Breeding Programs at the University of Washington (WSU; Puyallup, WA) the ARS USDA in Oregon (USDA-ARS; Corvallis) have been collaborated with many countries, including Canada, New Zealand and the United Kingdom. These breeding programs focus on the development of varieties suitable only for mechanized cultivation. Meeker, produced in 1967 through the WSU breeding program, suits well for this purpose, but is susceptible to RBDV and root rot. Despite great breeding achievements in recent years, Meeker is still the main variety for commercial production in North America [9-11].

In recent years, several industrial high-yielding varieties of WSU selection have been created: Willamette and Canby, Coho [11]. Currently, the modern commercial variety Lewis is widely cultivated in the United States, adapted to the Northwest Pacific coast and the Central and South regions of New Zealand. Later, the following varieties were created: Summit, Amity, Vintage and Kokanee, which significantly expanded the market for fresh berry products. New varieties such as Cascade Delight, Cascade Bounty and Cascade Harvest have been widely used for a long time. Due to their high resistance to root rot, they are in demand for the majority of US farmers [11-15].

In Canada, raspberry breeding has been carried out since the 1950s as part of the Agriculture and Agri-Food Canada (AAFC) program, thus ensuring the creation and introduction of new varieties for growers in the Pacific Northwest and around the world. The first varieties of AAFC raspberry selection, such as Haida, Chilcotin, Skeena and Nootka, have high quality fruits, stable and good yields. In 1989, the Chilliwack raspberry variety was created, which has become one of the most requested varieties in the world. Currently, it is cultivated in various climatic zones and is considered the benchmark for the fresh market. The later-developed varieties Esquimalt, Chemainus, Cowichan, Saanich, Nanoose, Ukee, and Rudi, are actively cultivated in North America and are being tested in Europe [15-19].

In the southern part of the United States, the North Carolina State University breeding program is coordinating its efforts to create heat-tolerant raspberry varieties [18, 19]. Mandarin was the first raspberry variety derived from the heat-resistant Asian species. The raspberry species R. parvifolius was adapted to hot and humid conditions.

In the Russian Federation, the main plantings of raspberries are concentrated in amateur gardening, where up to $70-90 \%$ of berry products are obtained. In personal farms, as a rule, the yield is $5-7 \mathrm{t} / \mathrm{ha}$ or more. This is $2-3$ times higher than in public plantings, which is associated with a higher level of agricultural technology, as well as timely and high-quality harvesting. However, personal farms are not able to provide the population of the entire country and the processing industry with berries due to the impossibility of using modern intensive technologies and seasonal harvesting. The full need for berries can be met only through the expansion of production plantations using innovative low-cost technologies and 
the creation of varieties adapted to these technologies [20].

In connection with the active demand for fresh and processed raspberries in the world market, there is a great need for the active expansion of industrial plantations, which is currently observed at the plantations of Russian farm agricultural enterprises. At the same time, labor costs significantly increase, since most of the main technological operations in the cultivation of raspberry crops are carried out manually [21-23]. To a large extent, it is possible to increase the economic efficiency in the cultivation of this crop by replacing the basic operations during cultivation with mechanized ones, including multiple harvesting [21-23].

It should be noted that at large industrial plantations the quality of berries is significantly higher due to improvement of the basic technological operations. Raspberry plantations with an area of more than 3 hectares are the most highly profitable. Many of them yield more than 8-10 t/ha. Many high-tech, advanced horticultural farms have plantations with average yields of 12-15 t/ha. Currently, the total number of plantations with an area of more than 3-5 hectares in Russia accounts for $30-40 \%$ of the total area of plantations of this crop [22-24].

In the EU, there is relatively high demand for both fresh berries and berries for processing. Much attention should be paid to the pricing policy of wholesaling and retail $[21,22,24]$.

Varieties with large and dense berries adapted to mechanized harvesting are most requested for cultivation in the central regions of Russia. One of the main limiting quality traits in the cultivation of raspberries is the density and size of the fruit. The density of berries is one of the main decisive conditions for preserving the marketable and consumer qualities of fruits during mechanized picking and further long-term transportation to the consumer $[23,24]$. After mechanized harvesting, raspberries with a low density quickly lose their presentation, become limp and release a lot of juice [23, 24].

Laboratory testing of conventional (non-remontant) raspberry varieties using harvesting equipment were carried out at the Kokinsky support point of the AllRussian Horticultural Institute for Breeding, Agrotechnology and Nursery (VSTISP) in 1980-1990. The experiments made it possible to establish the main indicators that ensure the suitability of varieties for machine harvesting $[2,4,5]$. The most important of them are the increased density of berries (not less than 7 $\mathrm{N})$. Also important are their good separability from fruit bearing under vibration shaking (removal force of 0.3 $0.6 \mathrm{~N}$ ), relatively amicable ripening (not less than $60 \%$ of the total yield at one harvesting). In this case, raspberry bushes should be compact with low (1.5-1.8 $\mathrm{m})$, thickened and elastic stems that do not linger under the weight of fruits [23, 24].

Thus, the world raspberry breeding considers the increased density of fruits as decisive, and the main quality of the berries, affecting the ability to completely mechanize the entire cycle of raspberry cultivation, including harvesting. This quality indicator allows one to solve several important and basic tasks at once when removing and promoting products to the consumer.

A prerequisite for the suitability of berries for machine harvesting is a good separation from the fruit crop, which ensures the optimal operating mode of the harvesting machine, minimal injury to shoots, reduced losses due to fragility of the stalks, and more complete collection of ripe fruits [21-24].

The aim of this work was to single out varieties and elite forms with an increased density of berries which can be used for mechanized harvesting from the genetic collection of red raspberries of the All-Russian Research Institute of Fruit Crops Breeding.

\section{Materials and methods}

The work was carried out at the All-Russian Research Institute of Fruit Crops Breeding in 2019-2020 at the collection and breeding plots of raspberries. The Institute is located in the Oryol region, $350 \mathrm{~km}$ south-west of Moscow. (36.079 ${ }^{\circ}$ longitude, $52.989^{\circ}$ latitude). The objects of research were 20 raspberry varieties of various selections and 15 elite forms (from controlled crossings and populations from free pollination). The layout of plants is $4.0 \times 0.5 \mathrm{~m}$.

The soils of the collection and selection sites are gray forest, medium loamy, acidic. On average, for 20192020 , at the sites of the berry crop selection, $\mathrm{pH}$ was at the level of 4.95 ; hydrolytic acidity was within $5.73 \mathrm{mg}$ equiv. $/ 100 \mathrm{~g}$. It had the following composition: $2.66 \%$ of humus; $16.0 \mathrm{mg}$ equiv $/ 100 \mathrm{~g}$ of $\mathrm{S} ; 13.0 \mathrm{mg}$ equiv. $/ 100 \mathrm{~g}$ of $\mathrm{CaO} ; 2.3 \mathrm{mg}$ equiv. $/ 100 \mathrm{~g}$ of $\mathrm{MgO} ; 9.8 \mathrm{mg} / 100 \mathrm{~g}$ of $\mathrm{P}_{2} \mathrm{O}_{5}, 9.5 \mathrm{mg} / 100 \mathrm{~g}$ of $\mathrm{K}_{2} \mathrm{O}$.

The climatic conditions of the study period were contrasting and not always favorable for the growth and development of raspberry plants of the summer type of fruiting.

The average monthly air temperature in June 2019 was $20.7{ }^{\circ} \mathrm{C}$, with total precipitation of $39 \mathrm{~mm}$, hydrothermal index (HI) of 0.33 , very arid conditions.

In July 2019 , the average monthly air temperature was $17.3{ }^{\circ} \mathrm{C}$, with total precipitation of $87 \mathrm{~mm}$, HI of 0.92. In August 2019, the average monthly air temperature was $17.2^{\circ} \mathrm{C}$, with total precipitation of 38 $\mathrm{mm}, \mathrm{HI}$ of 1.03 . In June 2020 , the average monthly air temperature was at the level of $20.3{ }^{\circ} \mathrm{C}$, with total precipitation of $70 \mathrm{~mm}, \mathrm{HI}$ of 1.17 , humid conditions. In July 2020, the average monthly temperature was 19.2 ${ }^{\circ} \mathrm{C}$, with total precipitation of $122 \mathrm{~mm}$, HI of 2.04 , very humid conditions. In August 2020, the actual average monthly air temperature was at the level of $17.6{ }^{\circ} \mathrm{C}$, with total precipitation of $16 \mathrm{~mm}$, HI of 0.29 (very arid conditions).

The great instability of climatic factors allowed us to more objectively study the collection and breeding material of raspberries in terms of fruit size and their physical and mechanical properties.

Evaluation of collection and selection forms of raspberries was carried out in accordance with the "Program and methodology for the selection of fruit, berry and nut crops", as well as with the "Program and 
methodology for the variety study of fruit, berry and nut crops $[25,26]$.

When studying the strength characteristics of fruits in the collection and selection sites, the number of berries of each sample and elite seedlings was 12 (4 in three replicates). The berry crushing force was determined using the force indicator "Plodotest", the device is designed to determine the crushing force of berries, fruits with a liquid or semi-liquid filling having a thin skin. The range of determined forces is from $0.098 \mathrm{~N}$ (G). All data were converted into international units Newtons $(1 \mathrm{~kg}=9.8 \mathrm{~N})$.

\section{Results and discussion}

The study of the size and strength of raspberries revealed some varietal differences in these parameters. A slight varietal dependence of the studied indicator on the genotype and meteorological factors was registered.

Glen Ampele, Glenlion, Glen Magma, Volnitsa, Lyachka, Maroseyka, Rannyaya Zarya, Sulamith, Peresvet, Brigantina, Sokolenok had the largest size of berries from collectible forms of raspberries for 20192020 , the average berry weight of these varieties was in the range of 4.0-7.7 g. All other varieties were averageand small-fruited, with berry weight in the range of 2.5$3.8 \mathrm{~g}$ (Table 1).

Table 1. Average berry weight for collectible forms of raspberry (2019-2020).

\begin{tabular}{|l|c|c|c|c|}
\hline Variety & $\begin{array}{c}\text { Weight of one } \\
\text { berry, }\end{array}$ & $\mathbf{~ m}$ & $\boldsymbol{\sigma}$ & $\mathbf{C v \%}$ \\
\hline Sputnitsa-st & 3.5 & 3.53 & 0.45 & 12.76 \\
\hline Cascad Delait & 3.6 & 3.70 & 0.26 & 7.15 \\
\hline Chemainus & 3.8 & 3.77 & 0.25 & 6.68 \\
\hline Glen Ampele & 7.7 & 7.87 & 0.15 & 1.94 \\
\hline Glen Lion & 4.0 & 4.16 & 0.32 & 7.78 \\
\hline Glen Magma & 4.2 & 4.23 & 0.25 & 5.94 \\
\hline Jvars & 2.5 & 3.17 & 0.76 & 4.12 \\
\hline Brigantina & 4.0 & 4.17 & 0.76 & 18.33 \\
\hline Volnitsa & 5.0 & 4.07 & 1.01 & 24.75 \\
\hline Zaryanka & 3.2 & 4.10 & 0.10 & 2.44 \\
\hline Illuziya & 4.3 & 4.57 & 0.31 & 6.69 \\
\hline Lazarevskaya & 3.0 & 3.40 & 0.53 & 15.56 \\
\hline Lyachka & 4.5 & 4.23 & 0.25 & 5.94 \\
\hline Maroseyka & 4.5 & 4.60 & 0.36 & 7.84 \\
\hline Peresvet & 4.2 & 4.03 & 0.47 & 11.72 \\
\hline Rannyaya Zarya & 4.5 & 4.70 & 0.26 & 5.63 \\
\hline Sokolenok & 4.2 & 4.57 & 0.40 & 8.85 \\
\hline Sulamith & 4.9 & 5.00 & 0.10 & 2.00 \\
\hline Fantaziya & 4.0 & 4.10 & 0.36 & 8.79 \\
\hline Yarkaya & 3.2 & 3.23 & 0.25 & 7.75 \\
\hline
\end{tabular}

In 2019, the highest density of berries was registered for the varieties Rannyaya Zarya $(8.3 \mathrm{~N})$, Lyachka (7.57 N) and Lazarevskaya (7.21 N) (Fig. 1).

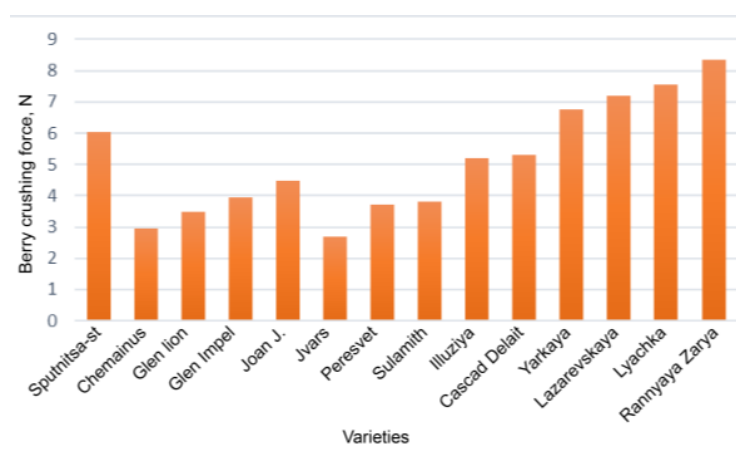

Fig. 1. Strength of raspberries of collection forms (2019).

The following varieties had the average density of berries: Yarkaya $(6.8 \mathrm{~N})$, Sputnitsa $(6.0 \mathrm{~N})$, Cascad Delait and Ilyuziya (about 5.2 N). All other varieties had low berry density (in the range of 2.9-4.5 N).

Among the 15 elite forms, 9-37; 9-18; 9-60; 9-70 had outstanding size of berries. Their berry size was in the range of 4.0-4.7 $\mathrm{g}$ (Table 2). The rest forms had an average berry weight of 3.2-3.9 $\mathrm{g}$.

Table 2. Average berry weight for elite forms of raspberry (2019-2020).

\begin{tabular}{|l|l|l|l|l|}
\hline Form & $\begin{array}{l}\text { Weight of } \\
\text { one berry, }\end{array}$ & $\mathbf{m}$ & $\boldsymbol{\sigma}$ & $\mathbf{C v \%}$ \\
\hline Sputnitsa-st & 3.5 & 3.53 & 0.45 & 12.76 \\
\hline $9-35$ & 3.2 & 3.20 & 0.30 & $9, .8$ \\
\hline $9-63$ & 3.5 & 3.57 & 0.50 & $1 ., 11$ \\
\hline $8-12$ & 3.2 & 3.43 & 0.21 & 6.06 \\
\hline $9-17$ & 3.6 & 3.67 & 0.31 & 8.33 \\
\hline $9-34$ & 3.6 & 3.63 & 0.25 & 6.93 \\
\hline $8-29$ & 3.7 & 3.87 & 0.15 & 3.95 \\
\hline $9-27$ & 3.7 & 3.93 & 0.21 & 5.29 \\
\hline $9-21$ & 3.8 & 3.83 & 0.15 & 3.98 \\
\hline $9-58$ & 3.8 & 3.77 & 0.15 & 4.06 \\
\hline $9-20$ & 3.9 & 4.00 & 0.23 & 6.61 \\
\hline $9-37$ & 4.0 & 4.03 & 0.25 & 6.21 \\
\hline $9-18$ & 4.1 & 4.3 & 0.20 & 4.65 \\
\hline $9-60$ & 4.2 & 4.33 & 0.15 & 3.53 \\
\hline $9-71$ & 4.6 & 4.53 & 0.31 & 6.74 \\
\hline $9-70$ & 4.7 & 4.83 & 0.15 & 3.16 \\
\hline
\end{tabular}

Among the elite forms in 2019, 9-27 (7.9 N), 9-20 $(7.7 \mathrm{~N}), 9-63(6.9 \mathrm{~N}), 8-12(6.9 \mathrm{~N})$ had outstanding maximum density of berries. The forms 9-35; 9-34; 960 ; 9-37; 9-70; 9-18 (6.8-4.9 N) had average density of berries. All other elite forms in terms of berry density were in the range of 4.8-3.8 N, which indicated low marketability (Fig. 2). 


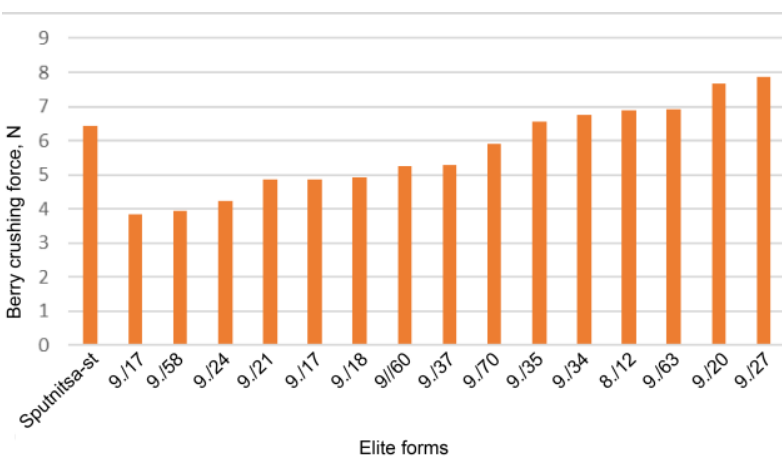

Fig. 2. Strength of raspberries of collection forms (2019).

In 2020, the maximum berry density was found in raspberry varieties Rannyaya Zarya $(8.35 \mathrm{~N})$, Lyachka $(7.0 \mathrm{~N})$, Lazarevskaya $(7.21 \mathrm{~N})$. Average berry density was registered for varieties Yarkaya $(6.7 \mathrm{~N})$, Sputnitsa $(6.03 \mathrm{~N})$, Cascad Delait (5.3 N), Illuziya (5.20 N), Joan J. (4.48 N), Arta 4.21 (N) (Fig. 3). The other raspberry varieties in 2020 showed low berry density in the range of 2.7-3.8 N. These varieties did not meet the requirements for mechanized harvesting.

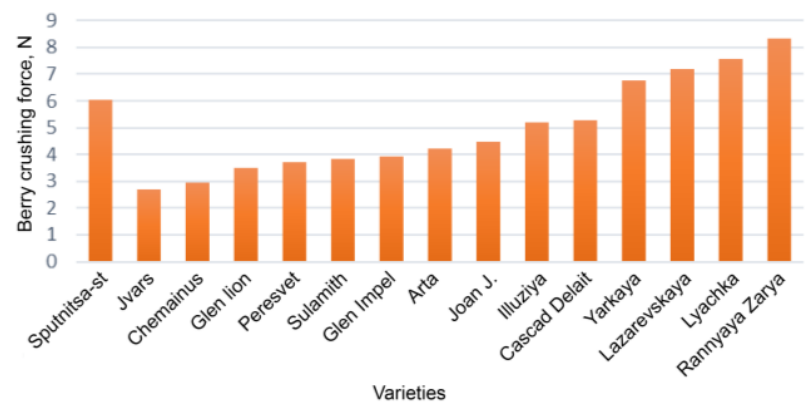

Fig. 3. Strength of raspberries of collection forms (2020).

In 2020 , the maximum berry density was registered for the 8-29 $(9.7 \mathrm{~N})$; 9-58 $(8.3 \mathrm{~N})$; 9-27 $(8.2 \mathrm{~N})$; 9-20; 8$12(7.3 \mathrm{~N})$ elite forms. The other elite forms had average berry density within 5.3-6.2 N. (Fig. 4).

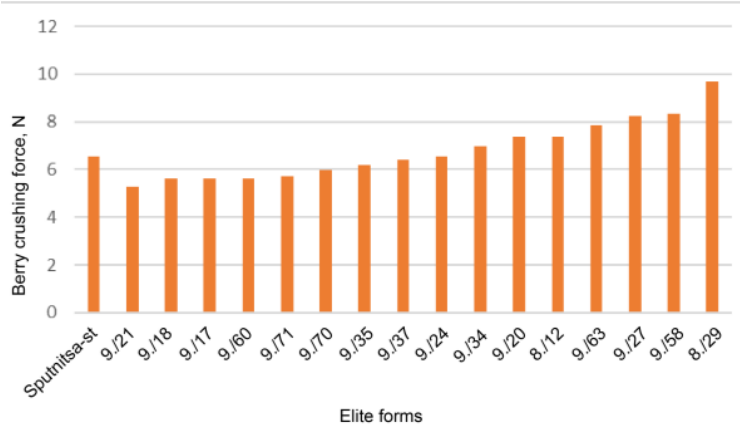

Fig. 4. Strength of raspberries of elite forms (2020).

\section{Conclusions}

1. The performed studies allowed us to select from the gene pool of red raspberries of the All-Russian Research Institute of Fruit Crops Breeding varieties with both large and dense fruits suitable for mechanized harvesting: Rannyaya Zarya, Lyachka, Lazarevskaya.
These varieties have relatively large and dense berries of 3.5-4.5 $\mathrm{g}$ each with a crushing force of 8.35-7.61 N.

2 . The hybrids $8-29 ; 9-58 ; 9-27$ are notable among the elite forms, having a berry crushing force in the range of 9.7-8.2 $\mathrm{N}$ and a berry size in the range of 3.8$4.0 \mathrm{~g}$.

\section{References}

1. Food and Agriculture Organization of the United Nations FAO Stat http://www.fao.org/faostat/en/\#data/QC. Access date 10.12.2020

2. Kazakov I.V., Evdokimenko S.N., Kulagina V.L. Agricultural Biology: No. 1, 28-33 (2009).

3. Fire Effects Information System (FEIS) https://www.feis-crs.org/feis/

4. Jennings D. L. Raspberries and Blackberries. Their Breeding, Deseases and Growth/Finn, C. Raspberry Cultivars: What's New? What's Succeeding? Where are Breeding Programs Headed? // IX International Rubus\&Ribes Symposium. Pucon, Chili. Acta Hort., 2008.

5. Knigh V.H. New Summer Fruiting Red Raspberry Cultivars from East Malling Research // IX International Rubus\&Ribes Symposium. Pucon, Chili, 1 January. Acta Hort., 2008. DOI: 10.17660/Acta Hortic. 2008. 777.

6. Jennings S.N., Graham J., Ferguson L., Young V. (2016). New developments in raspberry breeding in Scotland. Acta Hortic 1133:23-28 DOI: 10.17660/Acta Hortic 2016. 1133. 4

7. Orzel A., Simlat M., Danek J. (2016). Directions in raspberry and blackberry breeding programme cuonducted in NIWA Berry Breeding Ltd., Brzezna, Poland. Acta Hortic 1133:29-34 DOI: 10.17660/Acta Hortic. 2016. 1133. 5.

8. Danek J. (2008). Recent Situation in Raspberry Production in Poland. IX International Rubus\&Ribes Symposium. Pucon, Chili, 1 January. Acta Hort. DOI: 10.17660/Acta Hortic. 2008. 777. 43.

9. Finn CE. (2006). Caneberry breeders in North America. Hort science 41:22-24.

10. Stephens M., Enfield J., Hall H. (2012). 'Wakefield' red raspberry. Hortscience 47:1556-1558. DOI: https://doi.org/10.21273/HORTSCI.47.10.1556

11. Finn C.E., Lawrence F.J., Yorgey B., Strick B.C. (2001) 'Coho' red raspberry. Hortscience 36:11591161. DOI: 10.21273/HORTSCI.39.2.444

12. Moore P. (2004). 'Cascade delight' red raspberry. Hortscience 39(1):185-187

13. Moore P. (2006). 'Cascade dawn' red raspberry. Hortscience 41(3):857-859

14. Moore P., Finn C. (2007). 'Cascade bounty' red raspberry. Hortscience 42(2):393-396 DOI: https://doi.org/10.21273/HORTSCI.42.2.393 
15. Moore P., Hoashi-Erhardt W., Finn C., Martin R., Dossett M. (2015) 'Cascade harvest' red raspberry. Hortscience 50:624-627 24.

16. Kempler, C., Daubeny H., Harding B., Kowalenko C. (2005). 'Cowichan' red raspberry. Hortscience 40:1916-1918

17. Kempler C, Daubeny H., Frey L., Walters T. (2006) 'Chemainus' red raspberry. Hortscience 41:13641366 DOI: 10.21273/HORTSCI.41.5.1364

18. Kempler C., Daubeny H., Harding B., Baumann T, Finn C., Moore P., Sweeney M., Walters T. (2007). 'Saanich' red raspberry. Hortscience 42:176-178

19. Ballington JR. (2016.) The history of blackberry and raspberry breeding in the southern USA. ActaHortic 1133:13-22.

20. Kulikov I.M. Innovative opportunities for increasing the production of raspberries in Russia // Horticulture and viticulture. 2010. No. 6. P. 14-16.

21. Danshina O.V., Sazonov F.F. Pomiculture and small fruits culture in Russia, 2014; Vol. 39: 65-70

22. Kazakov I.V., Kulagina V.L. Collection of scientific papers. NIZISNP: Agrotechnics, selection and mechanization in berry growing of the Non-Black Earth Region. Moscow, 1988: 97-105.

23. Evdokimenko S.N., Podgaetsky M.A. Pomiculture and small fruits culture in Russia, 2019.Vol. 59: 294-300.

24. Kazakov I.V., Kulagina V.L. Collection of scientific papers. NIZISNP: Berry growing of the Non-Black Earth Region. Moscow, 1989: 17-25.

25. Kichina V.V., Kazakov I.V., Gruner L.A. Breeding raspberries and blackberries. In book: Program and methodology for the selection of fruit, berry and nut crops. Ed. E.N. Sedova: Oryol, VNIISPK publishing house. 1995: 368-386.

26. Kazakov I.V., Gruner L.A., Kichina V.V. Raspberries, blackberries and their hybrids. In book: Program and methodology for the study of varieties of fruit, berry and nut crops, Ed. E.N.Sedova and T.P. Ogoltsova: Orel, 1999: 184-185. 